\title{
Lack of virological and serological evidence for continued circulation of highly pathogenic avian influenza H5N8 virus in wild birds in the Netherlands, 14 November 2014 to 31 January 2016
}

\author{
MJ Poen ${ }^{12}$, JH Verhagen ${ }^{12}$, RJ Manvell ${ }^{3}$, I Brown ${ }^{3}$, TM Bestebroer ${ }^{1}$, S van der Vliet ${ }^{1}, 0$ Vuong ${ }^{1}$, RD Scheuer ${ }^{1}$, HP van der \\ Jeugd ${ }^{45}$, BA Nolet ${ }^{46}$, E Kleyheeg ${ }^{45}$, GJDM Müskens ${ }^{7}$, FA Majoor ${ }^{8}$, C Grund ${ }^{9}$, RAM Fouchier ${ }^{1}$ \\ 1. Erasmus MC, Department of Viroscience, Rotterdam, the Netherlands \\ 2. These authors contributed equally to this work \\ 3. Animal and Plant Health Agency (APHA) - Weybridge, Addlestone, Surrey, United Kingdom \\ 4. Netherlands Institute of Ecology (NIOO-KNAW), Department of Animal Ecology, Wageningen, the Netherlands \\ 5. Vogeltrekstation - Dutch Centre for Avian Migration and Demography (NIOO-KNAW), Wageningen, the Netherlands \\ 6. University of Amsterdam, Institute of Biodiversity and Ecosystem Dynamics, Computational Geo-Ecology, Amsterdam, the \\ Netherlands \\ 7. Alterra, Center for Ecosystem Studies, Wageningen University, Wageningen, the Netherlands \\ 8. Sovon, Dutch Centre for Field Ornithology, Nijmegen, the Netherland \\ 9. Friedrich-Loeffler-Institut, Greifswald - Insel Riems, Germany
}

Correspondence: Ron A M Fouchier (r.fouchier@erasmusmc.nl)

Citation style for this article:

Poen MJ, Verhagen JH, Manvell RJ, Brown I, Bestebroer TM, van der Vliet S, Vuong O, Scheuer RD, van der Jeugd HP, Nolet BA, Kleyheeg E, Müskens GJDM, Majoor FA, Grund C, Fouchier RAM. Lack of virological and serological evidence for continued circulation of highly pathogenic avian influenza H5N8 virus in wild birds in the Netherlands, 14 November 2014 to 31 January 2016. Euro Surveill. 2016;21(38):pii=30349. DOI: http://dx.doi.org/10.2807/1560-7917.ES.2016.21.38.30349

In 2014, ${ }_{5} \mathrm{~N} 8$ clade 2.3.4.4 highly pathogenic avian influenza (HPAl) viruses of the $A / G o o s e /$ Guangdong/1/1996 lineage emerged in poultry and wild birds in Asia, Europe and North America. Here, wild birds were extensively investigated in the Netherlands for HPAI $\mathrm{H}_{5} \mathrm{~N} 8$ virus (real-time polymerase chain reaction targeting the matrix and $\mathrm{H}_{5}$ gene) and antibody detection (haemagglutination inhibition and virus neutralisation assays) before, during and after the first virus detection in Europe in late 2014. Between 21 February 2015 and 31 January 2016, 7,337 bird samples were tested for the virus. One HPAI ${ }_{5} \mathrm{~N} 8$ virus-infected Eurasian wigeon (Anas penelope) sampled on 25 February 2015 was detected. Serological assays were performed on 1,443 samples, including 149 collected between 2007 and 2013, 945 between 14 November 2014 and 13 May 2015, and 349 between 1 September and 31 December 2015. Antibodies specific for HPAI $\mathrm{H}_{5}$ clade 2.3.4.4 were absent in wild bird sera obtained before 2014 and present in sera collected during and after the HPAI $\mathrm{H}_{5} \mathrm{~N} 8$ emergence in Europe, with antibody incidence declining after the 2014/15 winter. Our results indicate that the HPAI $\mathrm{H}_{5} \mathrm{~N} 8$ virus has not continued to circulate extensively in wild bird populations since the 2014/15 winter and that independent maintenance of the virus in these populations appears unlikely.

\section{Introduction}

Wild birds are the natural hosts of low pathogenic avian influenza (LPAI) viruses, which generally do not cause clinical signs of disease in these host species [1]. So far, virus subtypes $\mathrm{H}_{1}$ to $\mathrm{H}_{1} 6$ and $\mathrm{N}_{1}$ to $\mathrm{N}_{9}$ have been detected in wild birds, of which viruses of subtypes $\mathrm{H}_{5}$ and $\mathrm{H}_{7}$ have shown the ability to evolve to highly pathogenic avian influenza (HPAl) viruses in poultry, causing severe disease with high mortality in such animals. These HPAI viruses were historically mainly detected in rapidly contained sporadic outbreaks in poultry, until $\mathrm{H}_{5} \mathrm{~N}_{1}$ viruses of the $\mathrm{A} / \mathrm{Goose} /$ Guangdong/1/1996 (GsGd) lineage emerged in Asia in 1997. Subsequently, these viruses have continuously circulated in poultry with frequent detections in wild birds [2] and with significant expansion in global range.

HPAI H5N8 viruses of the GsGd lineage of clade 2.3.4.4 emerged in poultry and wild birds on multiple continents in 2014. The ancestral influenza $\mathrm{H}_{5} \mathrm{~N} 8$ virus to the strains causing outbreaks from 2014 onwards was first detected in China in 2010 in a captive-held mallard (Anas platyrhynchos) [3]. In early 2014, HPAI $\mathrm{H}_{5} \mathrm{~N} 8 \mathrm{GsGd}$ virus of clade 2.3.4.4 occurred for the first time in poultry in South Korea, soon after causing outbreaks also in Japan [4]. From late 2014 onwards, this virus spread to other areas of the world including Europe, North America, Russia and Taiwan [5-8]. The HPAI H5N8 virus detections in Europe were limited to sporadic cases in wild birds and a relatively small 
TABLE 1

Wild bird species sampled for virus detection during and after the emergence of highly pathogenic avian influenza H5N8 virus in Europe, the Netherlands, 21 February 2015-31 January 2016 ( $n=7,337$ animals)

\begin{tabular}{|c|c|c|c|c|c|c|c|c|c|c|}
\hline \multirow[b]{2}{*}{ Order } & \multirow[b]{2}{*}{ Family } & \multirow[b]{2}{*}{ Species } & \multicolumn{4}{|c|}{ During outbreak: 21 Feb 2015-13 May 2015} & \multicolumn{4}{|c|}{ After outbreak: 14 May 2015-31 Jan 2016} \\
\hline & & & $\begin{array}{c}\text { Birds } \\
\text { sampled } \\
\mathrm{N}\end{array}$ & $\begin{array}{l}\text { AlV- } \\
\text { positive } \\
\text { birds } \\
\mathrm{N}\end{array}$ & $\begin{array}{c}\text { H5-positive } \\
\text { birds } \\
\mathrm{N}\end{array}$ & Pathotype & $\begin{array}{c}\text { Birds } \\
\text { sampled } \\
\text { N }\end{array}$ & $\begin{array}{l}\text { AIV- } \\
\text { positive } \\
\text { birds } \\
N\end{array}$ & $\begin{array}{c}\text { H5-positive } \\
\text { birds } \\
\mathrm{N}\end{array}$ & Pathotype \\
\hline \multirow{18}{*}{ Anseriformes } & \multirow{10}{*}{ Ducks } & $\begin{array}{l}\text { Common pochard (Aythya } \\
\text { ferina) }\end{array}$ & 0 & 0 & 0 & NA & 1 & o & o & NA \\
\hline & & Common teal (Anas crecca) & 8 & 0 & 0 & NA & 221 & 39 & 4 & LPAI \\
\hline & & $\begin{array}{l}\text { Egyptian goose (Alopochen } \\
\text { aegyptiaca) }\end{array}$ & 58 & o & 0 & NA & 136 & o & o & NA \\
\hline & & $\begin{array}{l}\text { Eurasian wigeon (Anas } \\
\text { penelope) }\end{array}$ & 175 & 1 & 1 & HPAI & 1,034 & 101 & 2 & LPAI \\
\hline & & Gadwall (Anas strepera) & 1 & o & 0 & NA & 175 & 15 & 0 & NA \\
\hline & & Mallard (Anas platyrhynchos) & 748 & 50 & 0 & NA & 2,464 & 354 & 15 & LPAI \\
\hline & & $\begin{array}{l}\text { Mandarin duck (Aix } \\
\text { galericulata) }\end{array}$ & 2 & 0 & 0 & NA & o & o & 0 & NA \\
\hline & & Northern pintail (Anas acuta) & o & o & o & NA & 7 & 3 & o & NA \\
\hline & & $\begin{array}{l}\text { Northern shoveler (Anas } \\
\text { clypeata) }\end{array}$ & o & 0 & 0 & NA & 17 & 2 & o & NA \\
\hline & & Tufted duck (Aythya fuligula) & 0 & 0 & 0 & NA & 1 & 0 & 0 & NA \\
\hline & \multirow{7}{*}{ Geese } & $\begin{array}{l}\text { Barnacle goose (Branta } \\
\text { leucopsis) }\end{array}$ & 96 & 5 & 4 & LPAI & 926 & 3 & o & NA \\
\hline & & Bean goose (Anser fabalis) & o & o & o & NA & 8 & o & o & NA \\
\hline & & Brent goose (Branta bernicla) & 54 & o & o & NA & o & o & o & NA \\
\hline & & $\begin{array}{l}\text { Canada goose (Branta } \\
\text { canadensis) }\end{array}$ & 3 & o & o & NA & 72 & 0 & o & NA \\
\hline & & Greylag goose (Anser anser) & 59 & 0 & 0 & NA & 239 & o & 0 & NA \\
\hline & & $\begin{array}{l}\text { Pink-footed goose (Anser } \\
\text { brachyrhynchus) }\end{array}$ & 0 & o & 0 & NA & 1 & 0 & o & NA \\
\hline & & $\begin{array}{l}\text { Greater white-fronted goose } \\
\text { (Anser albifrons) }\end{array}$ & 0 & o & 0 & NA & 55 & o & 0 & NA \\
\hline & Swans & Mute swan (Cygnus olor) & 3 & 0 & 0 & NA & 31 & 1 & 0 & NA \\
\hline \multirow{11}{*}{ Charadriiformes } & \multirow{8}{*}{ Gulls } & $\begin{array}{l}\text { Black-headed gull } \\
\text { (Chroicocephalus ridibundus) }\end{array}$ & 84 & 0 & 0 & NA & 392 & 53 & o & NA \\
\hline & & $\begin{array}{l}\text { Caspian gull (Larus } \\
\text { cachinnans) }\end{array}$ & 4 & 0 & 0 & NA & 4 & 0 & o & NA \\
\hline & & Common gull (Larus canus) & 1 & 0 & 0 & NA & 18 & 0 & o & NA \\
\hline & & $\begin{array}{l}\text { Great black-backed gull (Larus } \\
\text { marinus) }\end{array}$ & 1 & 0 & 0 & NA & 0 & 0 & o & NA \\
\hline & & Herring gull (Larus argentatus) & 15 & 0 & 0 & NA & 32 & 2 & o & NA \\
\hline & & $\begin{array}{l}\text { Lesser black-backed gull } \\
\text { (Larus fuscus) }\end{array}$ & 0 & o & o & NA & 33 & 2 & o & NA \\
\hline & & $\begin{array}{l}\text { Mediterranean gull (Larus } \\
\text { melanocephalus) }\end{array}$ & 1 & 0 & 0 & NA & 3 & 1 & o & NA \\
\hline & & $\begin{array}{l}\text { Yellow-legged gull (Larus } \\
\text { michahellis) }\end{array}$ & 0 & 0 & 0 & NA & 1 & 0 & 0 & NA \\
\hline & Lapwings & $\begin{array}{l}\text { Northern lapwing (Vanellus } \\
\text { vanellus) }\end{array}$ & 6 & 0 & 0 & NA & 0 & 0 & o & NA \\
\hline & \multirow{2}{*}{ Terns } & Black tern (Chlidonias niger) & o & o & 0 & NA & 0 & 0 & o & NA \\
\hline & & Common tern (Sterna hirundo) & o & 0 & o & NA & 0 & 0 & o & NA \\
\hline Columbiformes & Pigeons & $\begin{array}{l}\text { Common wood-pigeon } \\
\text { (Columba palumbus) }\end{array}$ & 1 & 0 & 0 & NA & o & 0 & o & NA \\
\hline \multirow{3}{*}{ Gruiformes } & Coots & Common coot (Fulica atra) & 46 & 0 & 0 & NA & 92 & 0 & o & NA \\
\hline & \multirow[b]{2}{*}{ Rails } & Little crake (Porzana parva) & 0 & 0 & 0 & NA & 1 & 0 & o & NA \\
\hline & & $\begin{array}{l}\text { Common moorhen (Gallinula } \\
\text { chloropus) }\end{array}$ & 3 & 0 & 0 & NA & 4 & 0 & o & NA \\
\hline \multicolumn{3}{|l|}{ Total } & 1,369 & 56 & 5 & NA & 5,968 & 576 & 21 & NA \\
\hline
\end{tabular}

AIV: avian influenza virus; HPAl: highly pathogenic avian influenza; LPAI: low pathogenic avian influenza; N: number; NA: not applicable. Surveillance activities were intensified from 21 February to 13 May $2015(n=1,369)$ and 1 September to 31 December 2015 $(n=3,736)$. 
Wild bird species sampled for H5-specific antibody detection before, during and after the emergence of highly pathogenic avian influenza H5N8 virus in Europe, the Netherlands, 2007-2015 ( $\mathrm{n}=1,443$ )

\begin{tabular}{|c|c|c|c|c|c|}
\hline \multirow[b]{2}{*}{ Order } & \multirow[b]{2}{*}{ Family } & \multirow[b]{2}{*}{ Species } & \multicolumn{3}{|c|}{ Number of individuals sampled } \\
\hline & & & $\begin{array}{c}\text { Before } \\
\text { outbreak } \\
\text { (before 2014) }\end{array}$ & $\begin{array}{l}\text { During outbreak } \\
(14 \text { Nov 2014-13 } \\
\text { May 2015) }\end{array}$ & $\begin{array}{c}\text { After outbreak } \\
\text { (1 Sep 2015-31 Dec } \\
\text { 2015) }\end{array}$ \\
\hline \multirow{19}{*}{ Anseriformes } & \multirow{9}{*}{ Ducks } & Common teal (Anas crecca) & 0 & 15 & 111 \\
\hline & & Egyptian goose (Alopochen aegyptiaca) & 9 & 62 & 28 \\
\hline & & Eurasian wigeon (Anas penelope) & 0 & 78 & 46 \\
\hline & & Gadwall (Anas strepera) & 1 & 3 & 1 \\
\hline & & Mallard (Anas platyrhynchos) & 21 & 93 & 18 \\
\hline & & Mandarin duck (Aix galericulata) & 1 & 2 & 0 \\
\hline & & Northern pintail (Anas acuta) & 0 & 0 & 1 \\
\hline & & Northern shoveler (Anas clypeata) & 0 & 2 & 3 \\
\hline & & Ruddy shelduck (Tadorna ferruginea) & 1 & 0 & 0 \\
\hline & \multirow{7}{*}{ Geese } & Barnacle goose (Branta leucopsis) & 20 & 19 & 0 \\
\hline & & Bean goose (Anser fabalis) & 5 & 0 & 0 \\
\hline & & Brent goose (Branta bernicla) & 0 & 19 & 0 \\
\hline & & Greylag goose (Anser anser) & 0 & 2 & 0 \\
\hline & & $\begin{array}{c}\text { Lesser white-fronted goose (Anser } \\
\text { erythropus) }\end{array}$ & 0 & 3 & 0 \\
\hline & & Pink-footed goose (Anser brachyrhynchus) & 0 & 1 & 0 \\
\hline & & Greater white-fronted goose (Anser albifrons) & 20 & 77 & 0 \\
\hline & \multirow{3}{*}{ Swans } & $\begin{array}{c}\text { Bewick's swan (Cygnus columbianus } \\
\text { bewickii) }\end{array}$ & 0 & 20 & 0 \\
\hline & & Mute swan (Cygnus olor) & 10 & 90 & 29 \\
\hline & & Whooper swan (Cygnus cygnus) & 0 & 1 & 0 \\
\hline \multirow{8}{*}{ Charadriiformes } & \multirow{8}{*}{ Gulls } & $\begin{array}{l}\text { Black-headed gull (Chroicocephalus } \\
\text { ridibundus) }\end{array}$ & 20 & 262 & 31 \\
\hline & & Caspian gull (Larus cachinnans) & 0 & 6 & 3 \\
\hline & & Common gull (Larus canus) & 12 & 34 & 17 \\
\hline & & Great black-backed gull (Larus marinus) & 0 & 1 & 0 \\
\hline & & Herring gull (Larus argentatus) & 7 & 61 & 28 \\
\hline & & Lesser black-backed gull (Larus fuscus) & 1 & 3 & 8 \\
\hline & & $\begin{array}{l}\text { Mediterranean gull (Ichthyaetus } \\
\text { melanocephalus) }\end{array}$ & 2 & 1 & 0 \\
\hline & & Yellow-legged gull (Larus michahellis) & 0 & 0 & 1 \\
\hline \multirow{2}{*}{ Gruiformes } & \multirow{2}{*}{ Rails } & Common coot (Fulica atra) & 19 & 84 & 24 \\
\hline & & Moorhen (Gallinula chloropus) & 0 & 6 & 0 \\
\hline \multicolumn{3}{|l|}{ Total } & 149 & 945 & 349 \\
\hline
\end{tabular}

number of unrelated outbreaks in poultry. However in North America HPAI $\mathrm{H}_{5} \mathrm{~N} 8$ viruses reassorted with cocirculating LPAI viruses, giving rise to new $\mathrm{HPAI} \mathrm{H}_{5} \mathrm{~N}_{1}$ and $\mathrm{H}_{5} \mathrm{~N}_{2}$ virus subtypes that caused a large number of outbreaks in poultry with numerous detections in wild birds [9]. Despite mild clinical symptoms caused by infection with HPAI $\mathrm{H}_{5} \mathrm{~N} 8$ viruses of clade 2.3.4.4 in experimentally infected mammals [10-12] and ducks [11], the widespread detection and rapid global spread of HPAI $\mathrm{H}_{5}$ clade 2.3.4.4 viruses pose a potential threat to domestic and wild animals and should be studied further.

The major challenges in understanding the epidemiology of emerging influenza viruses in wild birds are the large numbers of potential host species and the usually short period of viral shedding, combined with the difficulty of catching and sampling representative numbers per species. For instance, mallards that were experimentally infected with $\mathrm{HPAI} \mathrm{H}_{5} \mathrm{~N} 8$ virus shed infectious virus in tracheal swabs for only up to 5 days post infection [11]. These impediments result in a low probability of detecting newly emerging avian influenza viruses in wild birds through active virological surveillance and result in a delay of implementation of effective control measures. Nevertheless, to date HPAI $\mathrm{H}_{5} \mathrm{~N} 8$ virus has been detected in 30 wild bird species. In addition to the host species previously described $[13,14]$, HPAI $\mathrm{H}_{5} \mathrm{~N} 8$ viruses have been detected in wild bird species belonging to the orders Anseriformes in Asia (Aythya 
Details of positive control sera titres from experimentally infected ferrets, a domestic duck, and a domestic goose with one low pathogenic (LPAI) H5 and different highly pathogenic avian influenza (HPAI) H5 clades ( $\mathrm{n}=8$ antisera)

\begin{tabular}{|c|c|c|c|c|c|c|c|c|c|c|c|}
\hline \multirow{4}{*}{ Antiserum raised against } & \multirow{4}{*}{ Characteristics } & \multirow{4}{*}{ Species } & \multirow{2}{*}{\multicolumn{6}{|c|}{ Haemagglutination inhibition assay }} & \multirow{2}{*}{\multicolumn{3}{|c|}{$\begin{array}{c}\text { Virus } \\
\begin{array}{c}\text { neutralisation } \\
\text { assay }\end{array} \\
\text { Viruses }\end{array}$}} \\
\hline & & & & & & & & & & & \\
\hline & & & \multirow{2}{*}{ LPAI } & \multicolumn{5}{|c|}{ HPAI clade } & \multicolumn{3}{|c|}{ HPAI clade } \\
\hline & & & & $1^{\mathrm{a}}$ & $2.1^{b}$ & $2.2^{\mathrm{c}}$ & $2.3^{d}$ & $2 \cdot 3 \cdot 4 \cdot 4^{\mathrm{e}}$ & $2.1^{\mathrm{b}}$ & $2.3^{d}$ & $2 \cdot 3 \cdot 4 \cdot 4^{\mathrm{e}}$ \\
\hline A/Mallard/Netherlands/3/1999 & LPAI $\mathrm{H}_{5} \mathrm{~N}_{2}$ & Ferret & 160 & $<10$ & $<10$ & $\ll 10$ & $<10$ & $<10$ & ND & ND & ND \\
\hline A/Viet Nam/1194/2004 & HPAI $\mathrm{H}_{5} \mathrm{~N}_{1}$ clade 1 & Ferret & $<10$ & 80 & $<10$ & $<10$ & $<10$ & $<10$ & ND & ND & ND \\
\hline $\mathrm{A} /$ Indonesia/5/2005 & HPAI ${ }_{5} \mathrm{~N}_{1}$ clade 2.1 & Ferret & $<10$ & $\ll 10$ & 120 & $<10$ & 60 & $<10$ & 80 & $<10$ & $<10$ \\
\hline A/Turkey/Turkey/1/2005 & HPAI $\mathrm{H}_{5} \mathrm{~N}_{1}$ clade 2.2 & Ferret & $<10$ & $<10$ & $<10$ & 1,280 & 60 & $<10$ & ND & ND & ND \\
\hline A/Anhui/1/2005 & HPAI $\mathrm{H}_{5} \mathrm{~N}_{1}$ clade 2.3 & Ferret & $<10$ & $<10$ & $<10$ & 20 & 320 & $<10$ & $<10$ & 160 & $<10$ \\
\hline $\begin{array}{l}\text { A/Chicken/Netherlands/ } \\
\text { EMC-3/2014 }\end{array}$ & HPAI $\mathrm{H}_{5} \mathrm{~N} 8$ clade 2.3 .4 .4 & Ferret & $\ll 10$ & $<10$ & $<10$ & $<10$ & $<10$ & 160 & $\ll 10$ & $<10$ & 40 \\
\hline Turkey/Germany/AR2487/2014 & HPAI $\mathrm{H}_{5} \mathrm{~N} 8$ clade $2.3 \cdot 4 \cdot 4$ & $\begin{array}{c}\text { Domestic } \\
\text { duck }\end{array}$ & $<10$ & $<10$ & $<10$ & $<10$ & $<10$ & 160 & ND & ND & ND \\
\hline Turkey/Germany/AR2487/2014 & HPAI H5N8 clade $2 \cdot 3 \cdot 4 \cdot 4$ & $\begin{array}{c}\text { Domestic } \\
\text { goose }\end{array}$ & $<10$ & $<10$ & $<10$ & $<10$ & $<10$ & 80 & ND & ND & ND \\
\hline
\end{tabular}

HPAI: highly pathogenic avian influenza; LPAI: low pathogenic avian influenza; ND: not determined.

Lowest serum dilution tested was 10. Titres indicating the reactivity of sera to viruses homologous to the viruses, which the sera were raised against are in bold.

${ }^{\text {a }}$ / Viet Nam/1194/2004.

${ }^{b} \mathrm{~A} /$ Indonesia/5/2005.

c A/Turkey/Turkey/1/2005.

${ }^{d}$ A/Anhui/1/2005.

e A/Chicken/Netherlands/EMC-3/2014

spp.) and North America (Branta spp.) [6]. In Europe, HPAI H5N8 viruses have been detected in bird species of the orders Anseriformes (Anas spp. and Cygnus spp.) and Charadriiformes (Larus spp.) [5,6,14].

To estimate the likelihood of the involvement of live wild birds in local and long distance movement of HPAI $\mathrm{H}_{5}$ viruses, information on recent exposure of wild bird populations to $\mathrm{HPAl} \mathrm{H}_{5} \mathrm{~N} 8$ viruses using serology, in addition to virology, would add substantial power to surveillance programmes. Studies with ferret sera have shown serological tests to have substantial discriminative power between antibodies directed to HPAI $\mathrm{H}_{5}$ viruses of different clades and LPAI $\mathrm{H}_{5}$ viruses using haemagglutination inhibition $(\mathrm{HI})$ assays $[12,15]$. Although less is known about serology in wild birds, a study on wild birds sampled in Europe and Mongolia showed that antigenic differences between the haemagglutinin (HA) of classical Eurasian LPAI $\mathrm{H}_{5}$ viruses and $\mathrm{GsGd}_{\mathrm{s}}$ lineage $\mathrm{HPAl} \mathrm{H}_{5}$ viruses can be used to define bird populations in which HPAI viruses have previously been circulating [16]. With regard to HPAI ${ }_{5} \mathrm{~N} 8$ viruses specifically, a 2014 South Korean serology study showed evidence of a rise of $\mathrm{H}_{5}$ virus antibodies occurring in long distance migratory duck species after the onset of the HPAI ${ }_{5} \mathrm{~N} 8$ virus emergence in South Korea [4].

In this study, in response to the emergence of HPAI $\mathrm{H}_{5} \mathrm{~N} 8$ virus in Europe, we present data on wild bird surveillance activities in the Netherlands, including results of virological and serological assays.

\section{Methods}

\section{Ethical statement}

The capture of free-living birds was approved by the Dutch Ministry of Economic Affairs based on the Flora and Fauna Act (permit number FF/75A/2009/067 and $\mathrm{FF} / 75 \mathrm{~A} / 2014 / 054)$. Handling and sampling of freeliving birds was approved by the Animal Experiment Committee of the Erasmus Medical Centre (permit number 122-11-31). Free-living birds were released into the wild after sampling and all efforts were made to minimise animal suffering throughout the studies.

\section{Study population}

Immediately after the first detection of HPAI $\mathrm{H}_{5} \mathrm{~N} 8$ virus in poultry in Europe, ongoing influenza surveillance activities in migrating and overwintering wild birds in the Netherlands were intensified (14 November 201413 May 2015). Hereafter, this period will be referred to as 'during the outbreak'. Surveillance activities in wild birds in the Netherlands were again intensified from the onset of the arrival of wild migrating birds a year after the initial HPAI $\mathrm{H}_{5} \mathrm{~N} 8$ virus detection in Europe (1 September-31 December 2015). This period will be referred to as 'after the outbreak'. Sampled populations consisted of resident birds, partial migrants and long distance migrants. During both periods of 
Detected haemagglutination inhibition antibody titres to low pathogenic avian influenza H5 virus ${ }^{\mathrm{a}}$ and to highly pathogenic avian influenza H5 clade 2.3.4.4 H5N8 virus ${ }^{\mathrm{b}}$ in birds, before, during, and after detection of the highly pathogenic avian influenza H5N8 virus in Europe, the Netherlands, 2007-2015 ( $\mathrm{n}=1,443$ birds)

\begin{tabular}{|c|c|c|c|c|c|c|c|c|c|c|c|}
\hline \multirow{2}{*}{ Strain } & \multirow{2}{*}{$\begin{array}{l}\text { Period relative to the } \\
\text { outbreak }\end{array}$} & \multicolumn{7}{|c|}{ Haemagglutination inhibition titre } & \multirow{2}{*}{$\begin{array}{c}\text { High } \\
\text { background }\end{array}$} & \multirow{2}{*}{$\begin{array}{l}\text { Total } \\
\text { tested }\end{array}$} & \multirow{2}{*}{$\begin{array}{c}\text { Total } \\
\text { positives }\end{array}$} \\
\hline & & BLD & $10-40$ & $40-80$ & $80-160$ & $160-320$ & $320-640$ & $\geq 640$ & & & \\
\hline \multirow{3}{*}{$\begin{array}{l}\text { LPAI } \\
\mathrm{H}_{5} \mathrm{N2}^{\mathrm{a}}\end{array}$} & Before & 121 & 1 & 0 & 1 & 0 & 0 & 0 & 26 & 149 & 2 \\
\hline & During & 903 & 16 & 5 & 2 & 1 & 0 & 0 & 18 & 945 & 24 \\
\hline & After & 324 & 2 & 1 & 0 & 2 & 0 & 0 & 20 & 349 & 5 \\
\hline \multirow{3}{*}{$\begin{array}{l}\mathrm{HPAl} \\
\mathrm{H}_{5} \mathrm{~N}^{\mathrm{b}}\end{array}$} & Before & 123 & 0 & 0 & 0 & 0 & 0 & 0 & 26 & 149 & 0 \\
\hline & During & 897 & 7 & 20 & 6 & 4 & 5 & 1 & 5 & 945 & 43 \\
\hline & After & 319 & 4 & 3 & 2 & 1 & 0 & 0 & 20 & 349 & 10 \\
\hline
\end{tabular}

BLD: below limit of detection; LPAI: low pathogenic avian influenza; HPAI: highly pathogenic avian influenza.

Lowest serum dilution tested was 10.

${ }^{a}$ A/Mallard/Netherlands/3/1999.

${ }^{b}$ A/Chicken/Netherlands/EMC-3/2014.

' The 'outbreak' refers to the six months following the detection of the highly pathogenic avian influenza $\mathrm{H}_{5} \mathrm{~N} 8 \mathrm{virus}$ in Europe and this extends from 14 November 2014 to 13 May 2015. The period before the 'outbreak' is from 2007 to 2013 , while the period after the 'outbreak' is from 1 September to 31 December 2015.

intensified surveillance, blood samples were obtained in addition to samples for virus detection. A matching historical set of serum samples was compiled based on similarity in species and family, hereafter referred to as 'before the outbreak' (2007-2013).

\section{Sample collection}

Wild birds were captured using duck decoys, clap nets, cannon nets, mist nets, leg-nooses, swan hooks, or manually. Birds were sampled routinely for virus detection using cloacal and/or oropharyngeal swabs as described elsewhere [14]. In addition, faecal samples were collected from a limited number of species for virus detection. Blood samples were collected for antibody detection. Blood samples were collected from the brachial or metatarsal vein and centrifuged at 3,000 rpm for $10 \mathrm{~min}$ in $0.8 \mathrm{~mL}$ gel separation tubes (MiniCollect tubes, Roche). Serum samples were stored below $-20^{\circ} \mathrm{C}$ until analysis.

Virus detection, isolation and characterisation Samples for virus detection were analysed for the presence of $\mathrm{HPAI}_{5}(\mathrm{~N} 8)$ virus using matrix- and $\mathrm{H}_{5}$-specific real-time polymerase chain reaction (RT-PCR) assays followed by $\mathrm{H}_{5}$ and neuraminidase sequencing as previously described [14]. Samples testing positive in matrix specific RT-PCR were inoculated in embryonated chicken eggs as described previously [17].

\section{Antibody detection}

Serum samples were first tested for the presence of $\mathrm{H}_{5}$-specific antibodies in an $\mathrm{HI}$ assay according to standard procedures [18]. Briefly, serum samples were incubated for 16 hours at $37^{\circ} \mathrm{C}$ with Vibrio cholerae filtrate containing receptor-destroying enzyme to remove non-specific inhibitors of haemagglutination activity, followed by incubation for 1 hour at $56^{\circ} \mathrm{C}$. Twofold serial dilutions of serum samples with a start dilution of 1:20 were prepared using phosphate-buffered saline (PBS) in U-bottomed 96 well microtitre plates. Serum dilutions were incubated with four haemagglutinating units (HAU) of Madin-Darby canine kidney (MDCK) (all HPAI $\mathrm{H}_{5}$ clade viruses) or egg (A/Mallard/ Netherlands/3/1999) cultured virus for $30 \mathrm{~min}$ at $37^{\circ} \mathrm{C}$. A suspension of $1 \%$ turkey red blood cells (TRBC) was added to the serum-virus dilutions. After incubation for 1 hour at $4^{\circ} \mathrm{C}$, haemagglutination patterns were read. Negative controls, based on serum incubation without virus, were used to measure non-specific haemagglutination of each serum sample. Sera showing high background (i.e. high non-specific haemagglutination) were pre-treated with $10 \%$ TRBC for 1 hour at $4^{\circ} \mathrm{C}$ and retested for the presence of $\mathrm{H}_{5}$-specific antibodies as described above. Serum samples from experimentally inoculated ferrets $[12,15]$, a domestic duck, and a domestic goose were used as positive controls.

All serum samples were initially screened for antibodies specific for classical Eurasian LPAI $\mathrm{H}_{5} \mathrm{~N}_{2}$ virus A/ Mallard/Netherlands/3/1999 and clade 2.3.4.4 HPAI $\mathrm{H}_{5} \mathrm{~N} 8$ virus $\mathrm{A} /$ Chicken/Netherlands/EMC-3/2014. Serum samples that tested positive for HPAI $\mathrm{H}_{5}$ clade 2.3.4.4-specific antibodies were further tested against HPAl viruses of the $\mathrm{H}_{5}$ clades 1 (A/Viet Nam/1194/2004), 2.1 (A/Indonesia/5/2005), 2.2 (A/ Turkey/Turkey/1/2005), and 2.3 (A/Anhui/1/2005), and retested against the clade 2.3.4.4 virus. Samples showing more than threefold differences in titre or testing negative in the second assay after showing initial titres were tested a third time. The viruses used were recombinant viruses based on an A/PR/8/34 virus backbone, containing the $\mathrm{HA}$ and neuraminidase (NA) of the representative $\mathrm{H}_{5}$ strains. The sequences of the $\mathrm{HA}$ genes were modified to remove the multi-basic cleavage site 
Birds species with antibodies to highly pathogenic avian influenza H5 clade 2.3.4.4 H5N8 virus ${ }^{\text {a }}$, and number of respective animals, according to their haemagglutination inhibition antibody titres to the virus, during and after detection of highly pathogenic avian influenza H5N8 virus in Europe, the Netherlands, 14 November 2014-31 December 2015 ( $\mathrm{n}=382$ birds)

\begin{tabular}{|c|c|c|c|c|c|c|c|c|c|c|}
\hline \multirow{2}{*}{ Species } & \multirow{2}{*}{$\begin{array}{l}\text { Period relative to the } \\
\text { outbreak }\end{array}$} & \multicolumn{7}{|c|}{$\mathrm{HI}$ titre to $\mathrm{HPAl} \mathrm{H}_{5}$ clade $2.3 .4 .4\left(\mathrm{H}_{5} \mathrm{~N} 8\right)$ virus } & \multirow{2}{*}{ High background } & \multirow{2}{*}{$\begin{array}{l}\text { Total } \\
\text { tested }\end{array}$} \\
\hline & & BLD & $10-40$ & $40-80$ & $80-160$ & $160-320$ & $320-640$ & $\geq 640$ & & \\
\hline $\begin{array}{l}\text { Eurasian wigeon } \\
\text { (Anas penelope) }\end{array}$ & During & 66 & 6 & 4 & 2 & 0 & 0 & 0 & 0 & 78 \\
\hline $\begin{array}{l}\text { Lesser white-fronted } \\
\text { goose (Anser } \\
\text { erythropus) }\end{array}$ & During & 2 & 0 & 1 & 0 & 0 & 0 & 0 & 0 & 3 \\
\hline $\begin{array}{l}\text { Mute swan (Cygnus } \\
\text { olor) }\end{array}$ & During & 59 & 1 & 14 & 4 & 4 & 5 & 1 & 2 & 90 \\
\hline $\begin{array}{l}\text { Common coot (Fulica } \\
\text { atra) }\end{array}$ & During & 83 & 0 & 1 & 0 & o & 0 & o & o & 84 \\
\hline $\begin{array}{l}\text { Eurasian wigeon } \\
\text { (Anas penelope) }\end{array}$ & After & 42 & 2 & 1 & 0 & 0 & 0 & 0 & 1 & 46 \\
\hline $\begin{array}{l}\text { Egyptian goose } \\
\text { (Alopochen } \\
\text { aegyptiaca) }\end{array}$ & After & 27 & 1 & 0 & 0 & 0 & 0 & 0 & 0 & 28 \\
\hline $\begin{array}{l}\text { Mute swan (Cygnus } \\
\text { olor) }\end{array}$ & After & 19 & 1 & 2 & 2 & 0 & 0 & 0 & 5 & 29 \\
\hline $\begin{array}{l}\text { Common coot (Fulica } \\
\text { atra) }\end{array}$ & After & 21 & 0 & 0 & 0 & 1 & 0 & 0 & 2 & 24 \\
\hline
\end{tabular}

BLD: below limit of detection; HI: haemagglutination inhibition; HPAI: highly pathogenic avian influenza.

Lowest serum dilution tested was 10.

a/Chicken/Netherlands/EMC-3/2014.

b The 'outbreak' refers to the six months following the detection of the highly pathogenic avian influenza H5N8 virus in Europe and this extends from 14 November 2014 to 13 May 2015. The period after the 'outbreak' is from 1 September to 31 December 2015.

to enable this study within biosafety level 2 laboratories. HPAI $\mathrm{H}_{5}$ virus of clade o was excluded from the analyses due to high overall reactivity with all avian positive control sera as previously described [16] and thus of limited discriminative value.

A representative selection (based on titre and serum availability) of serum samples that tested positive for HPAl $\mathrm{H}_{5}$ clade 2.3.4.4 antibodies were sent to the Animal and Plant Health Agency (APHA) (Weybridge, UK) for confirmation of HPAI $\mathrm{H}_{5}$ clade 2.3.4.4-specific antibodies using an $\mathrm{HI}$ assay. The $\mathrm{HI}$ assay procedure used by the APHA differed from the HI assay described above and was carried out in accordance to the World Organisation for Animal Health (OIE) [19]. In short, twofold serial dilutions of serum samples with a start dilution of 1:12 were made using phosphate-buffered saline (PBS) and prepared in V-bottomed microtitre plates. Serum dilutions were incubated with four HAU of egg cultured virus for $30 \mathrm{~min}$ at room temperature. A solution of $1 \%$ chicken red blood cells (CRBC) was added to the serum-virus dilutions. After incubation for 30 min at room temperature, haemagglutination patterns/ streaming of red cells were read. Polyclonal chicken sera raised against the same clade 2.1, 2.2, 2.3, and 2.3.4.4 viruses as mentioned above were used as positive controls, supplemented with LPAI $\mathrm{H}_{5} \mathrm{~N}_{3}$ virus A/ Teal/England/7394-2805/2006 and clade 2.3.4.4 HPAI $\mathrm{H}_{5} \mathrm{~N} 8$ virus A/Duck/England/36254/2014.
All samples that tested positive for $\mathrm{HPAl} \mathrm{H}_{5}$ clade 2.3.4.4-specific antibodies in the initial $\mathrm{HI}$ assay were tested in a virus neutralisation (VN) assay if sufficient amounts of serum were available. The VN assay was performed as described previously [20], using titrated virus stocks of clade 2.1, 2.3, and 2.3.4.4. Briefly, serum was heat inactivated for $30 \mathrm{~min}$ at $56^{\circ} \mathrm{C}$ and twofold serial dilutions of the sera starting at a 1:20 dilution were prepared and 100 median tissue culture infectious dose (TCID50) was added. After incubating antigen and serum for 1 hour at $37^{\circ} \mathrm{C}$ with $5 \% \mathrm{CO}_{2}$, the mixtures were transferred to 96 well flat bottom plates containing MDCK cells, which were washed once with infection medium before inoculation. The plates were incubated for 1 hour at $37^{\circ} \mathrm{C}$ with $5 \% \mathrm{CO}_{2}$, after which the cells were washed once with $100 \mu \mathrm{L}$ infection medium and the medium was replaced by $200 \mu \mathrm{L}$ infection medium. Three days later, a haemagglutination assay was performed with the supernatant to determine the antibody titres.

\section{Results}

\section{Study population}

A total of 11,355 birds were sampled for virus detection during and after the first detection of $\mathrm{HPAI}_{5} \mathrm{H}_{8}$ viruses in poultry and wild birds in Europe. Of those, 5,387 birds were sampled during the outbreak and 5,968 after the outbreak. This report describes the results 
TABLE 6A

Titres of confirmatory haemagglutination inhibition and virus neutralisation assays for sera positive for highly pathogenic avian influenza $\mathrm{H} 5$ clade 2.3.4.4-specific antibodies in the initial screening, the Netherlands, 14 November 2014-31

December 2015 ( $n=53$ serum samples)

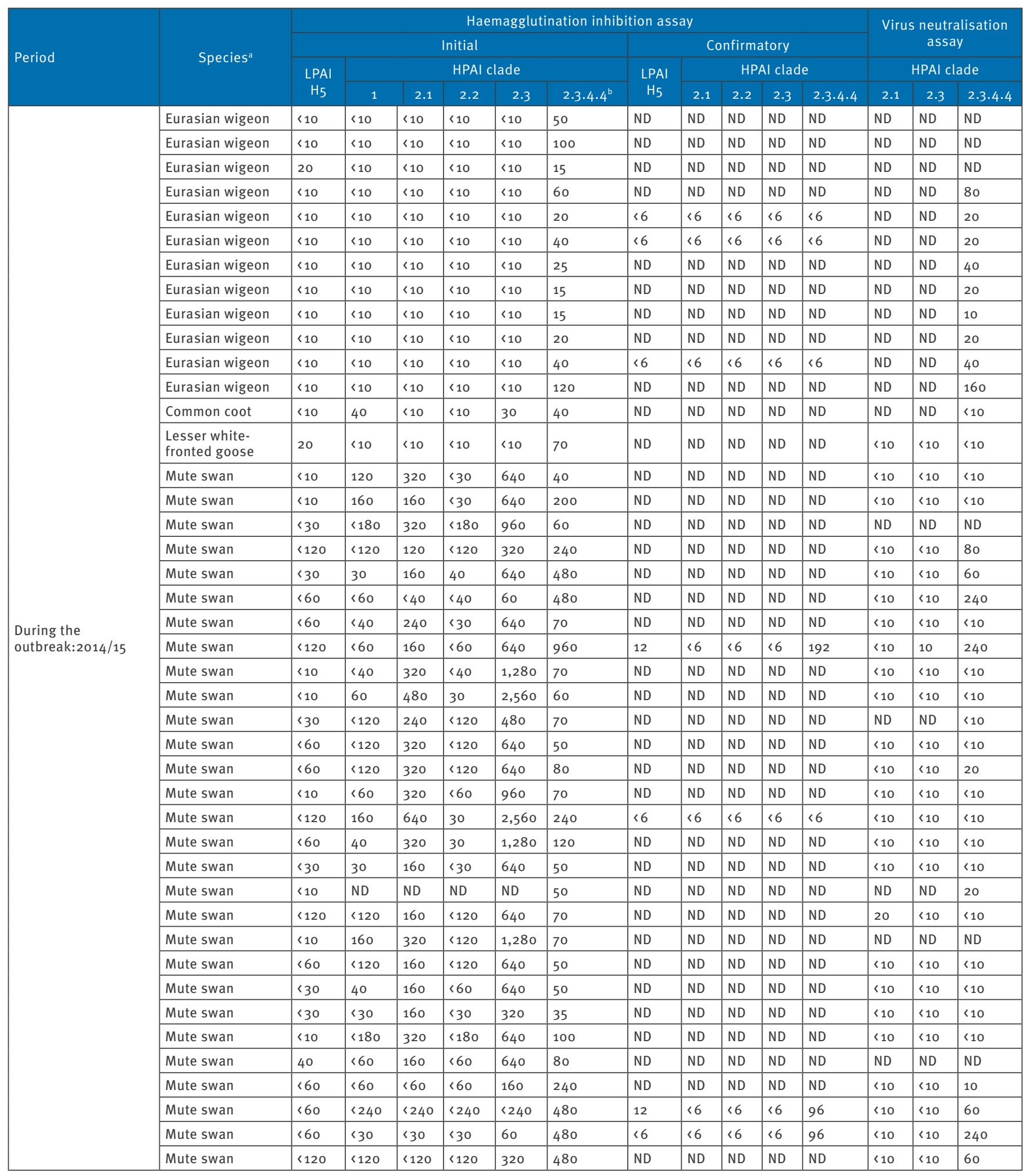

HPAI: highly pathogenic avian influenza; LPAI: low pathogenic avian influenza; ND: not determined.

Lowest serum dilution tested was 10 for the initial haemagglutination inhibition (HI) and virus neutralisation assay and 6 for the confirmatory $\mathrm{HI}$ assay.

a Species included common coot (Fulica atra), Egyptian goose (Alopochen aegyptiaca), Eurasian wigeon (Anas penelope), lesser white-fronted goose (Anser erythropus), mute swan (Cygnus olor).

${ }^{\mathrm{b}}$ Mean titre of in duplo tested samples. 
Titres of confirmatory haemagglutination inhibition and virus neutralisation assays for sera positive for highly pathogenic avian influenza H5 clade 2.3.4.4-specific antibodies in the initial screening, the Netherlands, 14 November 2014-31 December 2015 ( $n=53$ serum samples)

\begin{tabular}{|c|c|c|c|c|c|c|c|c|c|c|c|c|c|c|c|}
\hline \multirow{4}{*}{ Period } & \multirow{4}{*}{ Species $^{a}$} & \multicolumn{11}{|c|}{ Haemagglutination inhibition assay } & \multirow{2}{*}{\multicolumn{3}{|c|}{$\begin{array}{c}\text { Virus neutralisation } \\
\text { assay }\end{array}$}} \\
\hline & & \multicolumn{6}{|c|}{ Initial } & \multicolumn{5}{|c|}{ Confirmatory } & & & \\
\hline & & \multirow{2}{*}{$\begin{array}{l}\text { LPAI } \\
\mathrm{H}_{5}\end{array}$} & \multicolumn{5}{|c|}{ HPAI clade } & \multirow{2}{*}{$\begin{array}{l}\text { LPAI } \\
\mathrm{H}_{5}\end{array}$} & \multicolumn{4}{|c|}{ HPAI clade } & \multicolumn{3}{|c|}{ HPAI clade } \\
\hline & & & 1 & 2.1 & 2.2 & 2.3 & $2 \cdot 3 \cdot 4 \cdot 4^{b}$ & & 2.1 & 2.2 & 2.3 & $2 \cdot 3 \cdot 4 \cdot 4$ & 2.1 & 2.3 & $2 \cdot 3 \cdot 4 \cdot 4$ \\
\hline \multirow{10}{*}{$\begin{array}{l}\text { After the outbreak: } \\
2015\end{array}$} & Eurasian wigeon & $<10$ & $<10$ & $<10$ & $<10$ & $<10$ & 20 & ND & ND & ND & ND & ND & ND & ND & 160 \\
\hline & Eurasian wigeon & $<10$ & $<10$ & $<10$ & $<10$ & $<10$ & 10 & ND & ND & ND & ND & ND & ND & ND & 20 \\
\hline & Eurasian wigeon & $<10$ & $<10$ & $\langle 10$ & $<10$ & $<10$ & 40 & ND & ND & ND & ND & ND & ND & ND & 80 \\
\hline & Common coot & $<10$ & 80 & 60 & 60 & 320 & 160 & ND & ND & ND & ND & ND & ND & ND & 20 \\
\hline & Egyptian goose & $<10$ & $<10$ & $<10$ & $<10$ & 80 & 25 & ND & ND & ND & ND & ND & ND & ND & $<10$ \\
\hline & Mute swan & 160 & 80 & 60 & $<30$ & 160 & 120 & ND & ND & ND & ND & ND & $<10$ & $<10$ & 40 \\
\hline & Mute swan & 40 & 80 & 80 & 80 & 320 & 45 & ND & ND & ND & ND & ND & $<10$ & $<10$ & $<10$ \\
\hline & Mute swan & $<10$ & $<10$ & $<10$ & $<10$ & 30 & 15 & ND & ND & ND & ND & ND & $<10$ & $\langle 10$ & $<10$ \\
\hline & Mute swan & $<10$ & 80 & 80 & 80 & 320 & 60 & ND & ND & ND & ND & ND & $<10$ & $<10$ & $<10$ \\
\hline & Mute swan & $<10$ & 160 & 160 & 240 & 320 & 80 & ND & ND & ND & ND & ND & 80 & 20 & $<10$ \\
\hline
\end{tabular}

HPAI: highly pathogenic avian influenza; LPAI: low pathogenic avian influenza; ND: not determined.

Lowest serum dilution tested was 10 for the initial haemagglutination inhibition (HI) and virus neutralisation assay and 6 for the confirmatory HI assay.

a Species included common coot (Fulica atra), Egyptian goose (Alopochen aegyptiaca), Eurasian wigeon (Anas penelope), lesser white-fronted goose (Anser erythropus), mute swan (Cygnus olor).

${ }^{\mathrm{b}}$ Mean titre of in duplo tested samples.

on 7,337 samples obtained from 21 February 2015 onwards in addition to the previously reported 4,018 samples obtained until 20 February 2015 [14]. Sampled species mainly belonged to the orders Anseriformes, Charadriiformes and Gruiformes (Table 1 ).

For antibody detection, 1,443 serum samples were analysed. Among these, 945 samples from 25 avian species were obtained during the outbreak, while 349 samples from 15 species originated from after the outbreak. A total of 149 serum samples from 15 species sampled before the HPAI $\mathrm{H}_{5} \mathrm{~N} 8$ virus emergence, obtained between 2007 and 2013, served as controls (Table 2). The majority of these samples were collected from birds wintering in Dutch wetlands.

Virus detection, isolation and characterisation In addition to the two previously reported $\mathrm{HPAI} \mathrm{H}_{5} \mathrm{~N} 8$ virus-infected Eurasian wigeons detected in the Netherlands in November 2014 [14], the virus was detected in a third Eurasian wigeon faecal sample obtained on 25 February 2015 (1/1,369 birds sampled in 21 February-13 May 2015), near Ilpendam ( $52^{\circ} 28^{\prime} \mathrm{N}$ $\left.4^{\circ} 57^{\prime} \mathrm{E}\right)$ (GenBank accession numbers: AKH14448$\mathrm{AKH} 14459)$. Since then, no HPAI $\mathrm{H}_{5} \mathrm{~N} 8$ virus has been detected in any of the samples tested (0/5,968 birds sampled in 14 May 2015-31 January 2016) (Table 1).

\section{Influenza A $\mathrm{H} 5$ virus clade-specific antibody detection}

As shown previously, ferret antisera raised against prototype strains representing LPAI and HPAI $\mathrm{H}_{5}$ viruses of various clades showed almost exclusive reactivity with homologous viruses in $\mathrm{HI}$ assays [12] (Table 3). Importantly, a ferret antiserum raised against the clade 2.3.4.4 virus did not react with other $\mathrm{H}_{5}$ viruses, and antisera raised against other prototype $\mathrm{H}_{5}$ strains did not react with the clade 2.3.4.4 virus $\mathrm{A} /$ Chicken/ Netherlands/EMC-3/2014. Sera obtained upon inoculation of a domestic duck and a domestic goose with the clade 2.3.4.4 virus A/Turkey/Germany/AR2487/2014 reacted similar to the ferret clade 2.3.4.4 antiserum; no cross-reactivity was seen with other prototype $\mathrm{H}_{5}$ strains (Table 3 ). These data indicate that the antigenic differences between clade 2.3.4.4 HA and HA of LPAI and HPAl viruses belonging to other clades were sufficiently large to allow serological discrimination by $\mathrm{HI}$ assay.

\section{Influenza A virus $\mathrm{H} 5$-specific antibody detection in wild birds}

\section{Haemagglutination inhibition assays}

Of the serum samples initially tested in the $\mathrm{HI}$ assay with LPAI $\mathrm{H}_{5} \mathrm{~N}_{2}$ (A/Mallard/Netherlands/3/1999) and HPAI $\mathrm{H}_{5}$ clade 2.3.4.4 $\mathrm{H}_{5} \mathrm{~N} 8$ (A/Chicken/Netherlands/ EMC-3/2014) virus, LPAI H5-specific antibodies were detected in 31 of 1,443 serum samples and HPAI $\mathrm{H}_{5}$ clade $2 \cdot 3 \cdot 4 \cdot 4$-specific antibodies in 53 of 1,443 serum samples (Table 4). Among these, seven samples tested positive for both LPAI H5- and $\mathrm{HPAI}_{5}$ clade 2.3.4.4-specific antibodies. The incidence of LPAI H5-specific antibodies was similar before, during and after the HPAI $\mathrm{H}_{5} \mathrm{~N} 8$ virus emergence in Europe (Fisher exact test, 
$p=0.76$ before vs during the outbreak; $p=0.39$ during vs after the outbreak), while HPAI H5 clade 2.3.4.4-specific antibodies were detected exclusively in sera from five bird species, obtained during and after the HPAI $\mathrm{H}_{5} \mathrm{~N} 8$ virus emergence in Europe (Table 4, Table 5). The incidence of HPAI $\mathrm{H}_{5}$ clade 2.3.4.4-specific antibodies a year after the outbreak (10/329 (20 samples with high background excluded), 3.0\%) was lower than during the outbreak ( $43 / 940$ ( 5 samples with high background excluded), 4.6\%) (Fisher exact test, $p=0.27$ ).

Serum samples obtained during (43/940 (5 samples with high background excluded), 4.6\%) and after (10/329 (20 samples with high background excluded), $3.0 \%$ ) the outbreak that tested positive for HPAI $\mathrm{H}_{5}$ clade 2.3.4.4-specific antibodies were subsequently tested in an $\mathrm{HI}$ assay against prototype viruses of clades $1,2.1,2.2,2.3$, and 2.3.4.4. Of the sera collected during the outbreak, 29/90 mute swans (Cygnus olor), 12/78 Eurasian wigeons, $1 / 3$ lesser white-fronted geese (Anser erythropus) and $1 / 84$ common coots (Fulica atra) tested positive for HPAI $\mathrm{H}_{5}$ clade 2.3.4.4-specific antibodies (Table 5). In these HPAI H5 clade 2.3.4.4-specific antibody positive sera, no cross-reactivity was observed in sera of Eurasian wigeons (12/12) and the lesser white-fronted goose $(1 / 1)$. In contrast, the common coot (1/1) serum showed an additional titre to the clade 2.3 virus and sera of mute swans showed crossreactivity to clade $2.3(27 / 29), 2.1(23 / 29), 1$ (9/29) and $2.2(4 / 29)$ viruses. In the majority of samples (22/29), titres to clade 2.1 and 2.3 exceeded those detected to clade 2.3.4.4 (Table 6).

Of the sera collected after the outbreak, 5/29 mute swans, 3/46 Eurasian wigeons, 1/28 Egyptian geese (Alopochen aegyptiaca) and 1/24 common coots tested positive for HPAI $\mathrm{H}_{5}$ clade 2.3.4.4-specific antibodies (Table 5). The sera of the Eurasian wigeons reacted with HPAI H5N8 virus exclusively. However, the common coot as well as $1 / 5$ mute swans showed $\mathrm{HI}$ titres to all five $\mathrm{H}_{5}$ clades. The other $3 / 5$ mute swans showed $\mathrm{HI}$ titres to multiple but not all $\mathrm{H}_{5}$ clades, while $1 / 5$ mute swans and 1/1 Egyptian goose only showed an additional titre to clade 2.3 (Table 6).

Seven of the HPAI $\mathrm{H}_{5}$ clade 2.3.4.4-seropositive bird sera obtained during the outbreak, from four mute swans and three Eurasian wigeons, were retested in an $\mathrm{HI}$ assay at the APHA. Here, 3/4 mute swan samples with high initial $\mathrm{HI}$ antibody titres against $\mathrm{HPAI} \mathrm{H}_{5}$ clade 2.3.4.4 ( $\left.\mathrm{H}_{5} \mathrm{~N} 8\right)$ virus were confirmed. However, $1 / 4$ mute swan sera could not be confirmed, and HPAI $\mathrm{H}_{5}$ clade $2 \cdot 3 \cdot 4 \cdot 4$-specific antibodies were also not detected in $3 / 3$ sera of the Eurasian wigeons that had low antibody titres in the initial tests (Table 6).

\section{Virus neutralisation assays}

For 37/43 HPAI H5 clade 2.3.4.4-positive sera collected during and 10/10 sera collected after the outbreak, sufficient serum volumes were available for retesting in a VN assay. In this assay, HPAI $\mathrm{H}_{5}$ clade 2.3.4.4-specific antibodies were detected in sera of 9/9 Eurasian wigeons and of 10/26 mute swans obtained during the outbreak. Sera of the mute swans did not react with viruses of other $\mathrm{H}_{5}$ clades. HPAI $\mathrm{H}_{5}$ clade $2.3 \cdot 4 \cdot 4^{-}$-specific antibodies were not detected in the sera of the common coot and the lesser white-fronted goose by VN assay. HPAI $\mathrm{H}_{5}$ clade 2.3.4.4-specific antibodies were confirmed by VN assay in sera from 3/3 Eurasian wigeons, $1 / 5$ mute swans, $1 / 1$ common coot and $0 / 1$ Egyptian goose collected after the outbreak (Table 6).

\section{Discussion}

In this report surveillance data for HPAI $\mathrm{H}_{5} \mathrm{~N} 8$ in birds in the Netherlands are presented. In addition to bird samples previously investigated for the virus from 14 November 2014 to 20 February 2015, a new set of 7,337 samples obtained between 21 February 2015 and 31 January 2016 is analysed. One faecal sample obtained from a Eurasian wigeon (Anas penelope) on 25 February 2015 tested positive for the HPAI H5N8 virus, adding to the previous finding of the virus in two Eurasian wigeons in the country in late 2014 [14]. Virological surveillance moreover suggests that only very limited numbers of wild bird species were identified as potential hosts in Europe. Importantly, to the best of our knowledge, there are no reports of additional findings of $\mathrm{HPAl} \mathrm{H}_{5} \mathrm{~N} 8$ viruses in wild birds and poultry in Europe, since the last detection of the virus in February 2015 in the Netherlands.

Given the difficulty of detecting newly emerging HPAI virus strains in wild birds however, the application of a more sensitive and cost-effective method to detect potential host species is warranted. For this purpose, we performed serological assays specifically aimed to detect antibodies specific to HPAI $\mathrm{H}_{5}$ clade 2.3.4.4 viruses in a substantial number of sera obtained before, during, and after HPAI $\mathrm{H}_{5} \mathrm{~N} 8$ emergence in the Netherlands. Three potential HPAI $\mathrm{H}_{5} \mathrm{~N} 8$ host species were identified by $\mathrm{HI}$ assays and confirmed by $\mathrm{VN}$ assays; Eurasian wigeons, mute swans and common coots. Considering the results of virological studies performed worldwide since the onset of the HPAI $\mathrm{H}_{5} \mathrm{~N} 8$ virus emergence in early 2014, the detection of HPAI $\mathrm{H}_{5}$ clade 2.3.4.4-specific antibodies in these species is not surprising. HPAI $\mathrm{H}_{5} \mathrm{~N} 8$ virus was isolated from Eurasian wigeons in Russia [8] and the Netherlands [14], from mute swans in Sweden [6], and from a common coot in South Korea [21].

The serological results reported here were not entirely consistent between $\mathrm{HI}$ and $\mathrm{VN}$ assays and between $\mathrm{HI}$ assays performed in two different laboratories. Although low HI titres (e.g. in Eurasian wigeons) were reproducible within a laboratory with the same $\mathrm{HI}$ assay and a VN assay, they were not detected by $\mathrm{HI}$ assay in a second laboratory, potentially due to differences in the methods used and hence differences in sensitivity and specificity. High antibody titres in mute swan sera were reproduced by $\mathrm{HI}$ assay in a second laboratory and by VN assay, but low antibody titres in mute swans 
were not always reproduced. While it is thus clear that individual $\mathrm{HI}$ titres in avian sera obtained from a single test cannot be used reliably for diagnosis, use of serum panels from cohorts of birds, use of multiple tests to cross-validate results, a panel of relevant viruses and use of collections of control antisera may still enable the use of serological tests in support of $\mathrm{HPAl}_{5}$ surveillance studies.

Previously, $\mathrm{HI}$ assays were shown to be discriminative enough to detect antibodies in serum samples collected from free-living wild birds in Europe and Asia to be directed to either HPAI or LPAI $\mathrm{H}_{5}$ viruses. However, widely varying results were obtained as far as $\mathrm{HPAI} \mathrm{H}_{5}$ clade-specific antibodies were concerned [16]. In this study, most birds that tested positive for HPAI $\mathrm{H}_{5}$ clade 2.3.4.4-specific serum antibodies showed relative low $\mathrm{HI}$ titres. This is in accordance with findings based on experimental HPAI $\mathrm{H}_{5} \mathrm{~N} 8$ virus infections of ferrets [10-12], possibly indicating low immunogenicity upon infection. In addition, there is limited knowledge about the longevity of avian antibodies after naturally occurring infection with avian influenza viruses. Antibodies specific to LPAI viruses were detected up to several months after experimental or natural infection [22-24], whereas little is known about the duration of detection of antibodies specific to HPAl viruses with a reported maximum of detection of 28 days after experimental infection in domestic ducks [25]. To date, there is no knowledge on the effect of a prior exposure to an unrelated subtype or on the phenomena of antigenic sin in avian species. Hypothetically, low immunogenicity in combination with decreasing titres in time could be an explanation for the low incidence and relative low titres of antibodies detected in wild bird sera in this study.

In conclusion, our results provide evidence that clinically unaffected long distance migratory and local wild birds sampled in the Netherlands during the $\mathrm{H}_{5} \mathrm{~N} 8$ outbreak late 2014 and early 2015, and again late 2015, have been exposed to HPAI $\mathrm{H}_{5} \mathrm{~N} 8$ or closely related HPAI $\mathrm{H}_{5}$ clade 2.3.4.4 viruses and seroconverted upon exposure. Since HPAI H5N8 virus has not been detected in Europe since early 2015 and because HPAI $\mathrm{H}_{5}$ clade 2.3.4.4-specific antibody incidence decreased in time, we conclude that the virus has not circulated extensively at the breeding grounds in summer and upon the return of the birds to their wintering areas in the $2015 / 16$ winter. As a consequence, the newly emerging HPAI $\mathrm{H}_{5} \mathrm{~N} 8$ clade 2.3.4.4 virus subtype appears to have already disappeared from European wild birds indicating that sustained transmission and independent maintenance may be less likely. This is an important consideration in the ongoing evolution and ecology of these viruses in wild birds and the potential risks they pose for introduction to poultry and the pathways through which they might spread. Finally we recommend that serological tools be further optimised, harmonised, and validated for avian influenza surveillance studies in wild birds.
Acknowledgements

The authors thank Stefan van Nieuwkoop, Pascal Lexmond, Anne van der Linden, Judith Guldemeester, Manon de Briedé, Suzan Pas, David van de Vijver, Teunis en Joke de Vaal, Bert Pellegrom, Jan Berkouwer, Arie Keijzer, Jan en Lilian Slijkerman, Hans Zantinge, Roy Slaterus, Peter de Vries, Manon Kaandorp, Cynthia Lange, Joanne Malotaux, Jan Beekman, Alwin Hut, Peter Volten, Evert-Jan Epping, Harma Scholten, Ton Eggenhuizen, Henk Koffijberg, Gerben Tijsma, Cor van Aart, Henk ten Klooster, Sjoerd Dirksen, Jan van der Winden and the Kreupel tern research group for providing technical assistance and samples. We thank Ger van der Water for excellent logistical assistance. We gratefully acknowledge Timm Harder and Martin Beer (Friedlich Loeffler Institute, Germany) for providing positive control avian sera. This work was supported by The Dutch Ministry of Economic Affairs, European Research Council project FLUPLAN (250136), NIAID/NIH contract HHSN272201400008C, and Horizon 2020 project COMPARE.

\section{Conflict of interest}

None declared.

\section{Authors' contributions}

MP and JV: performing serological assays, compiling the data and drafting the manuscript; RM and IB: confirmatory serological assays; TB and SV: excellent technical assistance in preparing, performing and interpreting serological assays; OV and RS: analysing samples for virus detection; HJ, $\mathrm{BN}$ and EK: initiation of the study, providing field data; FM and GM: collecting field data; CG; providing positive control sera; RF: initiation of study, critically revised the manuscript.

\section{References}

1. Kuiken T. Is low pathogenic avian influenza virus virulent for wild waterbirds? Proc. Biol. Sci. 2013;280(1763):20130990. DOI: http://dx.doi.org/10.1098/rspb.2013.0990 .PMID: 23740783

2. Liu J, Xiao H, Lei F, Zhu Q, Qin K, Zhang XW, et al. Highly pathogenic $\mathrm{H}_{5} \mathrm{~N}_{1}$ influenza virus infection in migratory birds. Science. 2005;309(5738):1206. DOI: 10.1126/science.1115273 PMID: 16000410

3. Zhao K, Gu M, Zhong L, Duan Z, Zhang Y, Zhu Y, et al. Characterization of three $\mathrm{H}_{5} \mathrm{~N}_{5}$ and one $\mathrm{H}_{5} \mathrm{~N} 8$ highly pathogenic avian influenza viruses in China. Vet Microbiol. 2013;163(3-4):351-7. DOI: 10.1016/j.vetmic.2012.12.025 PMID: 23375651

4. Jeong J, Kang HM, Lee EK, Song BM, Kwon YK, Kim HR, et al. Highly pathogenic avian influenza virus ( $\left.\mathrm{H}_{5} \mathrm{~N} 8\right)$ in domestic poultry and its relationship with migratory birds in South Korea during 2014. Vet Microbiol. 2014;173(3-4):249-57. DOI: 10.1016/j.vetmic.2014.08.002 PMID: 25192767

5. World Organisation for Animal Health (OIE). Update on highly pathogenic avian influenza in animals (type $\mathrm{H}_{5}$ and H7). Paris: OIE; 2014. [Accessed 02 Feb 2016]. Available from: http://www.oie.int/animal-health-in-the-world/ update-on-avian-influenza/2014/

6. World Organisation for Animal Health (OIE). Update on highly pathogenic avian influenza in animals (type $\mathrm{H}_{5}$ and H7). Paris: OIE; 2015. [Accessed 02 Feb 2016]. Available from: http://www.oie.int/animal-health-in-the-world/ update-on-avian-influenza/2015/

7. Verhagen JH, Herfst S, Fouchier RAM. How a virus travels the world.Science. 2015;347(6222):616-7. DOI: 10.1126/science. aaa6724 PMID: 25657235

8. Marchenko VY, Susloparov IM, Kolosova NP, Goncharova NI, Shipovalov AV, Durymanov AG, et al. Influenza $A\left(\mathrm{H}_{5} \mathrm{~N} 8\right)$ virus 
isolation in Russia, 2014. Arch Virol. 2015;160(11):2857-60. DOI: 10.1007/s00705-015-2570-4 PMID: 26306756

9. Hall JS, Dusek RJ, Spackman E. Rapidly Expanding Range of Highly Pathogenic Avian Influenza Viruses.Emerg Infect Dis. 2015;21(7):1251-2. DOI: 10.3201/eid2107.150403 PMID: 26079209

10. Kim HM, Kim CK, Lee NJ, Chu H, Kang C, Kim K, et al. Pathogenesis of novel reassortant avian influenza virus $A$ $\left(\mathrm{H}_{5} \mathrm{~N} 8\right)$ Isolates in the ferret. Virology. 2015;481:136-41. DOI: 10.1016/j.virol.2015.02.042 PMID: 25776760

11. Kim YI, Pascua PN, Kwon HI, Lim GJ, Kim EH, Yoon SW, et al. Pathobiological features of a novel, highly pathogenic avian influenza $A\left(\mathrm{H}_{5} \mathrm{~N} 8\right)$ virus. Emerg Microbes Infect. 2014;3(10):e75. DOI: 10.1038/emi.2014.75 PMID: 26038499

12. Richard M, Herfst S, van den Brand JMA, Lexmond P, Bestebroer TM, Rimmelzwaan GF, et al. Low Virulence and Lack of Airborne Transmission of the Dutch Highly Pathogenic Avian Influenza Virus $\mathrm{H}_{5} \mathrm{~N} 8$ in Ferrets. PLoS One. 2015;10(6):e0129827. DOI: 10.1371/journal.pone.0129827 PMID: 26090682

13. European Food Safety Authority (EFSA). Highly pathogenic avian influenza A subtype $H_{5}$ N8.EFSA Journal.2014;12(12):3941. DOI: $10.2903 /$ j.efsa.2014.3941

14. Verhagen JH, van der Jeugd HP, Nolet BA, Slaterus R, Kharitonov SP, de Vries PP, et al. Wild bird surveillance around outbreaks of highly pathogenic avian influenza $A\left(\mathrm{H}_{5} \mathrm{~N} 8\right)$ virus in the Netherlands, 2014, within the context of global flyways. Euro Surveill. 2015;20(12):21069. DOI: 10.2807/15607917.ES2015.20.12.21069 PMID: 25846491

15. Koel BF, van der Vliet S, Burke DF, Bestebroer TM, Bharoto EE, Yasa IWW, et al. Antigenic variation of clade $2.1 \mathrm{H}_{5} \mathrm{~N}_{1}$ virus is determined by a few amino acid substitutions immediately adjacent to the receptor binding site. MBio. 2014;5(3):e0107014. DOI: $10.1128 / \mathrm{mBi} 0.01070-14$ PMID: 24917596

16. Gilbert M, Koel BF, Bestebroer TM, Lewis NS, Smith DJ, Fouchier RAM. Serological evidence for non-lethal exposures of Mongolian wild birds to highly pathogenic avian influenza $\mathrm{H}_{5} \mathrm{~N}_{1}$ virus.PLoS One. 2014;9(12):e113569. DOI: 10.1371/ journal.pone.0113569 PMID: 25502318

17. Munster VJ, Baas C, Lexmond P, Bestebroer TM, Guldemeester $J$, Beyer WE, et al. Practical considerations for highthroughput influenza A virus surveillance studies of wild birds by use of molecular diagnostic tests. J Clin Microbiol. 2009;47(3):666-73. DOI: 10.1128/JCM.01625-08 PMID: 19109483

18. Hirst GK. Studies of Antigenic Differences among Strains of Influenza a by Means of Red Cell Agglutination.J Exp Med. 1943;78(5):407-23. DOI: 10.1084/jem.78.5.407 PMID: 19871338

19. World Organisation for Animal Health (OIE). Ch. 2.3.4. Avian Influenza (infection with avian influenza viruses). OIE Terrestrial Manual 2015. Paris: OIE; 2015. [Accessed o2 Feb 2016]. Available from: http://www.oie.int/fileadmin/Home/ eng/Health_standards/tahm/2.03.04_Al.pdf

20. Rimmelzwaan GF, Baars M, van Beek R, de Lijster P, de Jong JC, Claas EC, et al. Influenza virus subtype cross-reactivities of haemagglutination inhibiting and virus neutralising serum antibodies induced by infection or vaccination with an ISCOMbased vaccine. Vaccine. 1999;17(20-21):2512-6. DOI: 10.1016/ S0264-410X(99)00063-8 PMID: 10418897

21. Kim HR, Kwon YK, Jang I, Lee YJ, Kang HM, Lee EK, et al. Pathologic changes in wild birds infected with highly pathogenic avian influenza $\mathrm{A}\left(\mathrm{H}_{5} \mathrm{~N} 8\right)$ viruses, South-Korea, 2014. Emerg Infect Dis. 2015;21(5):775-80. DOI: 10.3201/ eid2105.141967 PMID: 25897841

22. Brown J, Poulson R, Carter D, Lebarbenchon C, PantinJackwood M, Spackman E, et al. Susceptibility of avian species to North American $\mathrm{H}_{13}$ low pathogenic avian influenza viruses. Avian Dis. 2012;56(4) Suppl;969-75. DOI: 10.1637/10158-040912-Reg.1 PMID: 23402121

23. Tolf C, Latorre-Margalef N, Wille M, Bengtsson D, Gunnarsson $\mathrm{G}, \mathrm{Grosbois} \mathrm{V,} \mathrm{et} \mathrm{al.} \mathrm{Individual} \mathrm{variation} \mathrm{in} \mathrm{influenza} \mathrm{A}$ virus infection histories and long-term immune responses in Mallards. PLoS One. 2013;8(4):e61201. DOI: 10.1371/journal. pone.0061201 PMID: 23637797

24. Verhagen JH, Höfle U, van Amerongen G, van de Bildt M, Majoor F, Fouchier RAM, et al. Long-Term Effect of Serial Infections with $\mathrm{H}_{13}$ and $\mathrm{H}_{1} 6$ Low-Pathogenic Avian Influenza Viruses in Black-Headed Gulls. J Virol. 2015;89(22):11507-22. DOI: $10.1128 /$ JVI.01765-15 PMID: 26339062

25. Wibawa H, Henning J, Waluyati DE, Usman TB, Lowther S, Bingham J, et al. Comparison of serological assays for detecting antibodies in ducks exposed to $\mathrm{H}_{5}$ subtype avian influenza virus. BMC Vet Res. 2012;8:117. DOI: 10.1186/17466148-8-117 PMID: 22823985

\section{License and copyright}

This is an open-access article distributed under the terms of the Creative Commons Attribution (CC BY 4.0) Licence. You may share and adapt the material, but must give appropriate credit to the source, provide a link to the licence, and indicate if changes were made.

This article is copyright of the authors, 2016. 